\title{
Development of a Magnetic Beads Quantitative Detection System for Fast Diagnosis
}

\author{
Yujiro Yamamoto Non-member (Asahi Kasei E-materials Corporation) \\ Tomohiro Morishita Non-member (Asahi Kasei Microdevices Corporation) \\ Kenji Matsuyama Non-member (Asahi Kasei Corporation) \\ Kenji Takasa Non-member (Asahi Kasei Corporation) \\ Ichiro Shibasaki Member (The Noguchi Institute)
}

Keywords : magnetic beads, magnetic sensor, semiconductor magnetic resistance, immunoassay

We developed a novel detection system for magnetic beads, suitable for rapid diagnostic detection system. The system consists of a semiconductor based magneto-resistance sensor for beads detection and a lateral flow kit.

Fig. 1 shows the immunoassay principle. Anti-bodies, which react with the target antigens, are adsorbed on reaction surface of the apparatus. Both target anti-gen and magnetic beads labeled antibody, which react with the antigen are added on the reaction surface which is furthermore washed after immunoassay. By washing the reaction surface, only reacted beads will remain, and by measuring the number of remained magnetic beads adsorbed on the reaction surface with a magnetic sensor, the quantity of antigens can be determined.

Fig. 2 shows a lateral flow kit, developed for immunoassay.

The immunoassay occurs when a target anti-gen is injected to the injection area and flows to the reaction surface by capillary phenomenon, reacting with the anti-body which is labeled with magnetic beads. Fig. 3 shows the magnetic beads detection system. In the developed system, an SMR (Semiconductor Magnetic

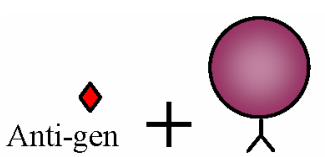

Magnetic beads labeled anti-body

Reaction surface

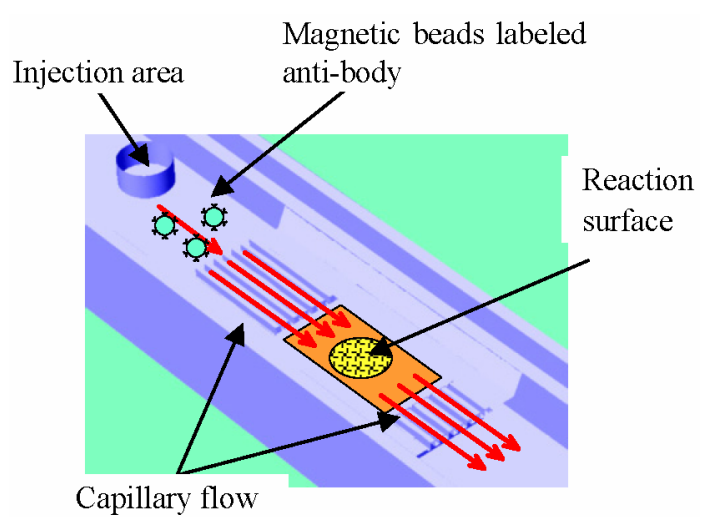

Fig. 2. Lateral flow kit for immunoassay
Resistance) magnetic sensor was used, because of its low cost, popularity and stability.

After immunoassay reaction, the lateral flow kit (containing adsorbed beads) is attached to the machine and afterwards move to the SMR sensor, while the reaction surface is scanned and counted by the system. Using this technique, the quantity of magnetic beads, adsorbed on the reaction surface can be measured.

Fig. 4 shows the evaluated result of the developed system. Detection of anti-gen of H.influenza at concentration of $0.1 \mathrm{ng} / \mathrm{ml}$ was performed with satisfactory sensitivity, showing the system to be promising for high-speed immunoassay.

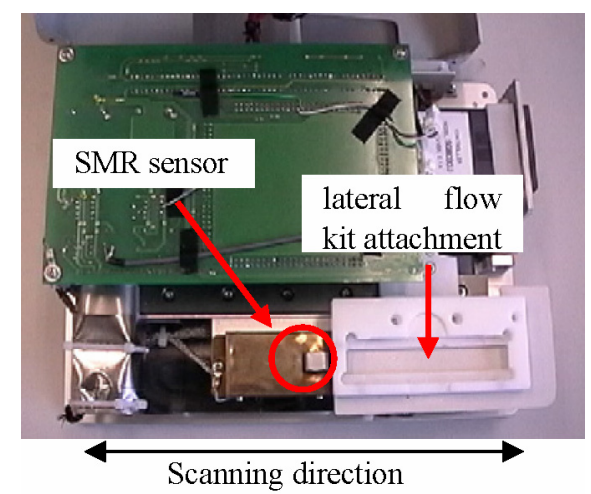

Fig. 3. Magnetic beads detection system

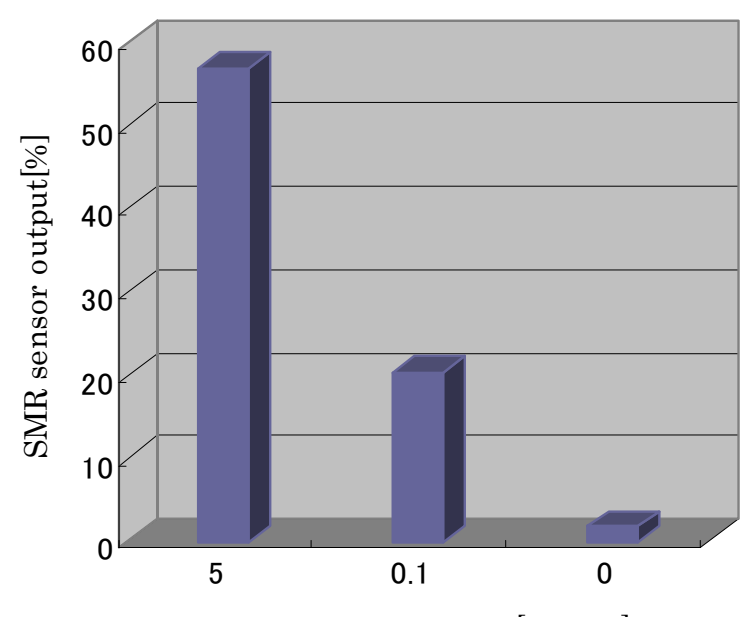

Anti-gen concentration[ng/mL] 


\section{迅速診断のための磁気ビーズ定量システムの開発}

$\begin{array}{lll}\text { 非会員 山本裕二郎* } & \text { 非会員 森下 } & \text { 朋浩** } \\ \text { 非会員 松山 健二*** } & \text { 非会員 高佐 健治*** } \\ \text { 正 員 柴㠃 一郎**** } & & \end{array}$

\section{Development of a Magnetic Beads Quantitative Detection System for Fast Diagnosis}

Yujiro Yamamoto*, Non-member, Tomohiro Morishita**, Non-member, Kenji Matsuyama***, Non-member,

Kenji Takasa***, Non-member, Ichiro Shibasaki****, Member

This paper reports the development and performance of a detection system for magnetic beads. The system consists of a semiconductor based magneto-resistance sensor for beads detection and a lateral flow kit. Detection of anti-gen of H.Influenza at concentration of $0.1 \mathrm{ng} / \mathrm{ml}$ was performed with satisfactory sensitivity, showing the system to be a promising for immunoassay.

キーワード : 磁気ビーズ, 磁気センサ, 半導体磁気抵抗素子, 免疫反応

Keywords : magnetic beads, magnetic sensor, semiconductor magnetic resistance, immunoassay

\section{1. はじめに}

臨床現場で検査を行い，その結果を診療に反映させ，適 切な治療に役立てることを目的とした迅速診断キットの開 発には，多くのメーカーが注力しており，またその市場も 拡大を続けている。このような迅速診断キットは 100 種類 以上あり ${ }^{(1)}$, インフルエンザウィルス診断キットなどがあ る。

迅速診断キットの測定法には，「イムノクロマトグラフィ 一法」「ラテックス凝集法」「酵素免疫法」があり，陽性・ 陰性の評価は一般に目視で行われる(2)。

迅速診断キットには，「簡便」「迅速」の利点がある一方

で，目視検査であるために，

・微弱陽性では陽性・陰性の判定が検査技師に依存する

・健常者にも存在する被検出物質を対象とした場合には, 定量化できないため, 陽性・陰性の判断ができない

* 旭化成イーマテリアルズ (株)

†416-8501 静岡県富士市鮫島 2-1

Asahi Kasei E-Materials Corporation

2-1, Samejima, Fuji-shi, Shizuoka 416-8501

** 旭化成エレクトロニクス (株)

干416-8501 静岡県富士市鮫島 2-1

Asahi Kasei Microdevices Corporation

2-1, Samejima, Fuji-shi, Shizuoka 416-8501

*** 旭化成 (株)

T416-8501 静岡県富士市鮫島 2-1

Asahi Kasei Corporation

2-1, Samejima, Fuji-shi, Shizuoka 416-8501

(財) 野口研究所

T173-0003 東京都板橋区加賀 1-8-1

The Noguchi Institute

1-8-1, Kaga Itabashi-ku, Tokyo 173-0003
などの欠点がある。

このような現状に対し，我々は「定量化可能な迅速診断」 という将来ニーズを見据え,「磁気ビーズ」と「磁気センサ」 を用いた「迅速診断システム」の開発を行った。本稿では， 磁気ビーズ測定システムとその性能について報告する。

迅速診断キット測定法としてイムノクロマトグラフィー 法が広く使用されている。イムノクロマトグラフィーで用 いられる反応原理を Fig. 1 に示す。反応部位に, 抗体を固定 化しておき，一方，金コロイド，ラテックスといった，粒 子状の物質で，二次抗体を標識化しておく。抗原を含む検 体液が, 添加されると, 抗原と粒子標識化二次抗体が結合 し，更に反応部位でサンドイッチ反応が発生し，結果的に， 反応部位に標識粒子が凝集する。この凝集を観測すること で，抗原の有無を判断する。

イムノクロマトグラフィー法とは，検体から被検出物質 を抽出した液を診断キットに滴下し, 毛細管現象を利用し て液輸送を行い, 反応部で免疫反応を行う方法である。被 検出物質の有無を評価するために用いる標識物質には，金 コロイドや色素含有ラテックスビーズが用いられる。この

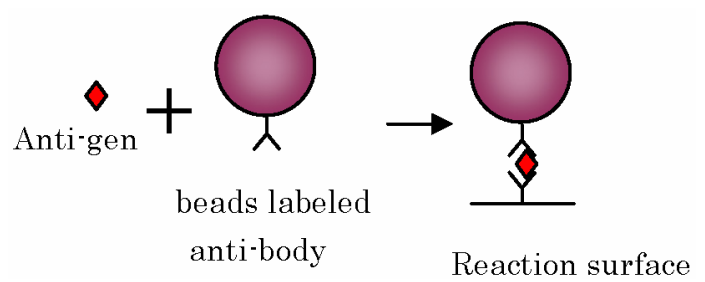

Fig. 1. Principle of immunoassay 
方法では，検出している物理量は「金コロイド・色素の吸 収」であり，装置を用いることで被検出物質の定量は可能 となる。しかしながら, 「検出系感度」の観点では, 標識物 質自体が信号を発するわけではないので, 高感度化は困難 である。

今回我々は，従来の光検出法に対し，「磁気ビーズ」を標 識物質とし，磁気センサを用いる磁気検出法に着目した。 この場合, 信号発生源が「磁気ビーズ」自体であるために, 磁気センサの選択・信号処理回路の最適化により, 検出系 感度の向上が期待でき，また装置としても安価である。

磁気検出法で使用する磁気センサとしては，ホール素子 やピックアップコイル，半導体磁気抵抗素子などがある。 ホール素子やピックアップコイルでは, 磁場発生源として 電磁石を用いるが，コイルのインダクタンスによる発熱が 大きく装置の信頼性の点に課題がある。

以上を踏まえ, 我々は「簡便性」「高汎用性」「定量可能」 「システムの小型化」「安価」の観点から，半導体磁気抵抗 素子（Semiconductor Magnetic Resistance，以下 SMR 素子) を磁気センサとして選択し,「被検出物質量を定量化可能な 迅速診断システム」の開発を行った。

本稿では, 磁気ビーズ検出の基本原理, プロトタイプシ ステムの開発，ラテラルフローキットの開発，最終的な迅 速診断システムの開発について報告する。

\section{2. 磁気ビーズ検出システムの基本原理}

〈2·1〉磁気ビーズを用いた免疫反応原理 イムノク ロマトグラフィー法で, 標識物質として用いられる金コロ イドやラテックスビーズの粒径は $10 \mathrm{~nm}-100 \mathrm{~nm}$ であるのに 対し, 磁気ビーズの粒径は数 $100 \mathrm{~nm}$ 一数 $1000 \mathrm{~nm}$ あり, 抗体 の大きさの数十倍一数百倍と非常に大きい。

そこで，磁気ビーズを標識物質とした場合の免疫反応性 について検証した。抗体に磁気ビーズを標識するには，ピ アース社製 EZ-link Sulfo-NHS-Biotinylation_Kit 試薬を用い て, Anti-C-Polysaccharide 抗体のビオチン化を行い, ビオチ ン化した抗体とアビジン-磁気ビーズを, PBS (Phosphate Buffered Saline) 中で反応させて得る, といった方法がある(3)。 反応原理は Fig. 1 で述べた抗原抗体反応を用いている。反応 表面に, 被検出物質である抗原に反応する抗体を吸着させ ており，この表面に抗原と磁気ビーズを標識した抗体とを 添加する。反応終了後には, 洗浄液で反応表面を洗浄する。 抗原がない場合は, 磁気ビーズの付着はなく, 抗原が存在 する場合は，抗原濃度に応じて磁気ビーズが反応表面に吸 着される。

Fig. 2 に反応後の表面を CCD カメラで評価した結果を示 す。今回の検討では，疎水性に改質した約 $5 \mathrm{~mm}$ 角の $\mathrm{Si}$ ウェ 八表面を反応表面とし，磁気ビーズには Dynal 社製 M-270 （粒子径 $2.8 \mu \mathrm{m} ）$ を用いた。Fig. 2 の黒い凝集が, 磁気ビーズ の凝集であり, 高濃度品で, 直径約 $3 \mathrm{~mm}$ である。Fig. 2 に 示すように，抗原濃度に依存した結果が得られ，磁気ビー ズを標識物質とした場合においても，免疫反応により抗原

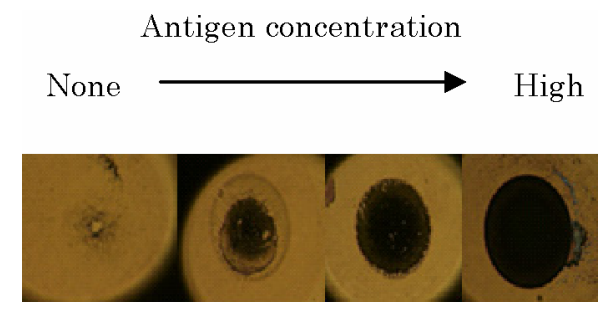

Fig. 2. Results of immunoassay, using magnetic beads

の検出が可能であることを実証した。

〈2·2〉磁気ビーズの選定磁気ビーズを用いた検出 システムでは, 磁気センサ測定感度の点からは, 「磁性体材 料の磁化率の高さ」「磁性体含有量が高いこと」が磁気ビー ズの特性として要求される。一方, 免疫反応性の点からは, より反応性のよい，比較的小さな磁気ビーズが好ましい。

そこで「測定感度」と「免疫反応性」の 2 点を両立しう る磁気ビーズの選定を行った。

磁気ビーズの選定にあたっては，「粒径」「磁性体含有量」 の異なる数種の磁気ビーズを標識物質として用い, 疎水性 に改質した Si ウェハ表面上で免疫反応を行い，評価した。 磁気センサとしては, SMR 素子を用い, 信号出力を比較し た。検討の結果, 本システムの磁気ビーズとして, Dynal 社 製 MyOne（粒子径 $1 \mu \mathrm{m}$ ，磁性体含有量 26\%）を採用した。

〈2·3〉磁気ビーズ検出原理先に述べたように「簡 便性」「高汎用性」「定量可能」「システムの小型化」の観点 から磁気センサとして, SMR 素子（村田製作所製）を用い た。

SMR 素子は, 磁場変化を感じる半導体薄膜からなる感磁 部, 磁場を与えるバイアス磁石から構成される。

磁気ビーズ検出原理を以下に説明する。Fig. 3(a)に示すよ うに, 各抵抗が R1, R2 である感磁部を直列に接続し, 外部 電圧 V c c 印加すると, 中点電位 V1 は,

$$
V 1=\frac{R 1}{(R 1+R 2)} \times V c c
$$

となる。

Fig. 3(b)に示すように，一方の感磁部直下に磁気ビーズが 存在した場合には，磁気ビーズによりバイアス磁石からの 磁場は収束され，ローレンツ力の作用により各感磁部の抵 抗は, R1 が R3 へ, R2 が R4 へと変化する。中点電位 V2 は,

$$
V 2=\frac{R 3}{(R 3+R 4)} \times V c c
$$

となる。

その結果, 感磁部直下に磁気ビーズが存在する際の検出 信号強度 Vは，

$$
V=V 1-V 2
$$

で表される。

つまり, SMR センサに対して, 磁気ビーズを一方向に走 査すると, Fig. 3(c)に示すような, 波形が得られることとな 


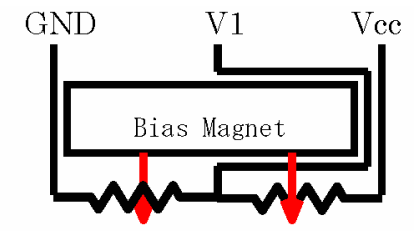

R1

$\mathrm{R} 2$

(a)

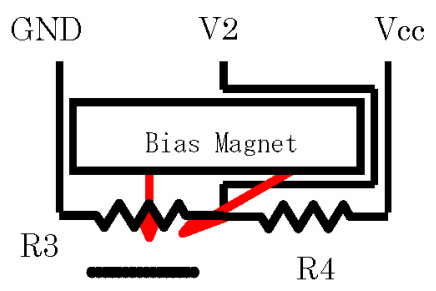

Magnetic Beads

(b)

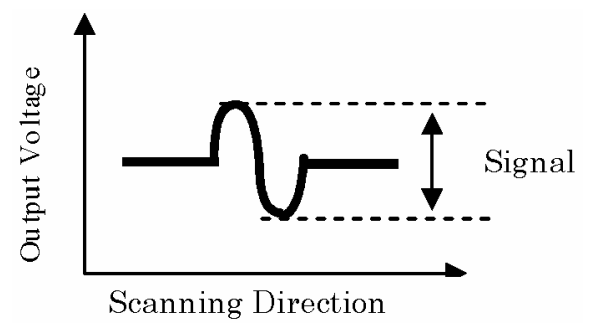

(c)

Fig. 3. Principle of detection of magnetic beads

る。磁場の収束による磁束密度が変化が磁気ビーズの量に より変化するため, 磁気ビーズ量の定量が可能となる。

\section{3. プロトタイプシステムの試作}

2 種類のプロトタイプシステムを試作し, 評価した。

Fig. 4(a)に示すように, プロトタイプI では, SMR 素子に 対して, 磁気ビーズサンプルを一方向に走査し, 磁気ビー ズ信号を検出する。プロトタイプII では，SMR 素子に対し て, 磁気ビーズサンプルを同心円上に回転させて, 磁気ビ ーズ信号を検出する。

SMR 素子からの検出信号は, 信号処理回路内で約 18 万倍 増幅し, $\mathrm{S} / \mathrm{N}$ 向上のためにバンドパスフィルタによるノイズ 除去を行った。また，25回積算を行うことでノイズ除去し， 磁気ビーズからの信号出力とした。

〈3・1〉プロトタイプ I 評価表面を疎水化した Si ウ エハ表面に, 免疫反応により磁気ビーズを吸着させたサン プルを用い，プロトタイプI の信号出力を評価した。

免疫反応の被検出抗原には, S.pneumoniae 菌及び H.Influenza 菌を用いた。Fig. 5(a)は S.pneumoniae 菌の検出例, Fig. 5(b)は H.Influenza 菌の検出例である。

Fig. 5 に示すように, 信号強度は抗原濃度に従って変化し ており，今回試作したプロトタイプI を用いれば，検体中 の抗原濃度を定量できることを実証した。

しかしながら，試作したプロトタイプIは，単純で簡便 な測定方法である一方で, 磁気ビーズサンプルの加速・減

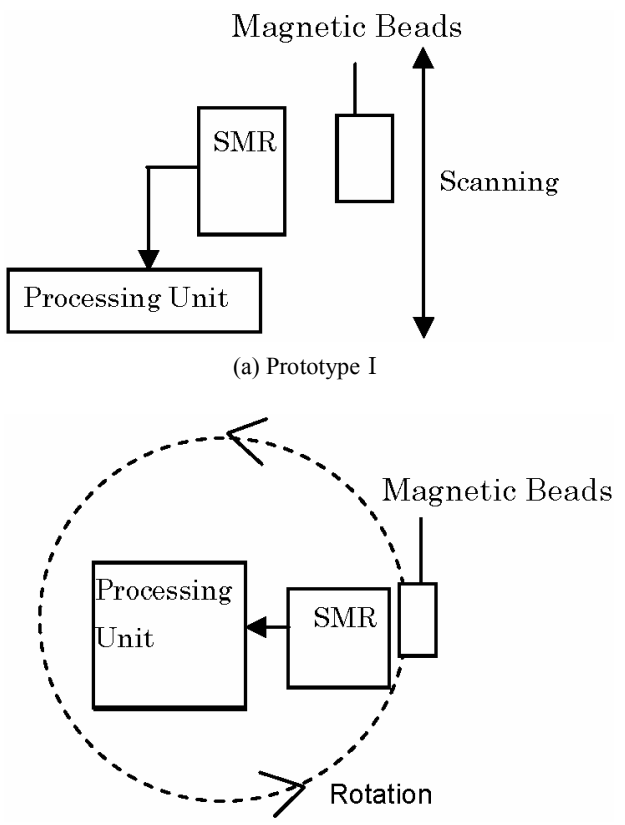

(b) Prototype II

Fig. 4. Prototype systems for beads detection

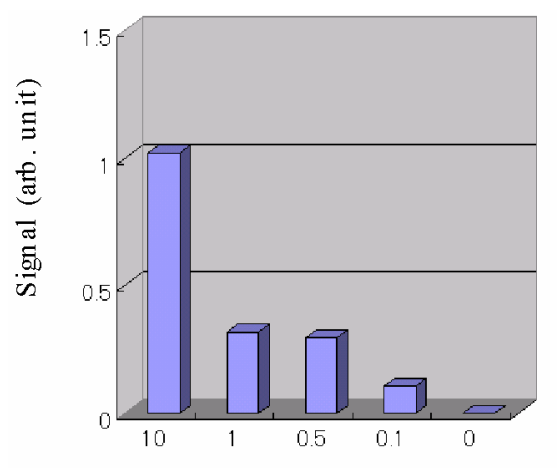

Antigen Concentration [ng/mL]

(a) S.pneumoniae

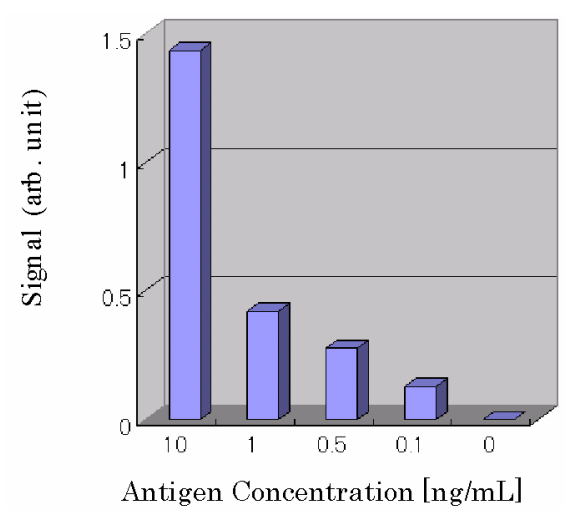

(b) H.Influenza

Fig. 5. Results of anti-gen detection with prototype I

速のために一定距離が必要なため, 装置サイズが大きくな る点, 駆動部のベアリングの耐久性などの課題があるため, 我々はプロトタイプIIについても評価を行った。 
〈3·2〉 プロトタイプII 評価上記のプロトタイプ I に想定される課題に対し, プロトタイプIIの長所は, 磁気 ビーズサンプルを回転させて信号出力を得るために，加 速・減速のための距離を必要とせず, 駆動部のベアリング の劣化も軽減できる点にある。

プロトタイプ I の評価時と同様に, 免疫反応により磁気 ビーズを Si ウェハ上に吸着させ，信号強度を評価した。

その結果, プロトタイプI と比較して, プロトタイプII では，信号強度が低下した。

プロトタイプI に対し，プロトタイプII では接触ノイズ の発生を防ぐために, 磁気ビーズサンプルと SMR 素子間の 距離を広く設定していることが要因と考えられる。

Fig. 6(a)には。磁気ビーズ量の異なる 3 種類のサンプル （強，中，弱）について信号強度の SMR 素子と磁気ビーズ 間距離依存性を示す。全てのサンプルで強い距離依存性が 観測された。Fig. 6(b)には, 距離 $300 \mu \mathrm{m}$ の際の信号強度で規 格化した際の結果を示す。この結果から, SMR 素子の出力 信号は磁気ビーズ量に関わらず，SMR 素子と磁気ビーズ間 距離に対して同じ傾向を示すことがわかり，検出感度の点 からは, SMR 素子と磁気ビーズの距離が非常に重要な要因 であることがわかった。

以上の結果から，プロトタイプ I の設計思想を基本とし， 量産機としての「迅速診断システムの開発」を推進した。

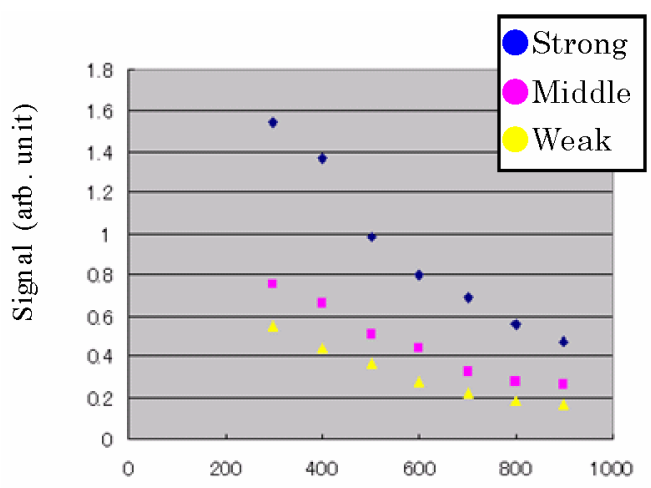

Distance between SMR \& Magnetic Beads [um]

(a)

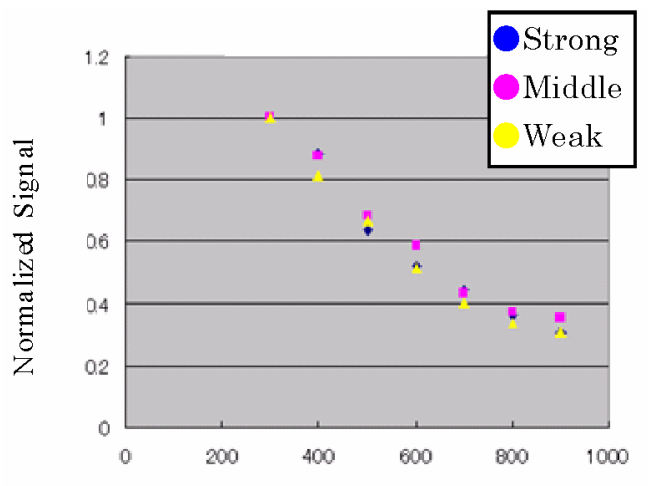

Distance between SMR \& Magnetic Beads [um] (b)

Fig. 6. Dependence of signal intensity on the distance between SMR and magnetic beads

\section{4. ラテラルフローキットの作成}

検体から被検出物質を抽出し, 抽出液を滴下寸る操作だ けで, 免疫反応が可能な簡易キット（以下，ラテラルフロ 一キット）の作製を行った。

Fig. 7(a)は，ラテラルフローキットの概観図である。キッ 卜は，ポリカーボネート樹脂を射出成形したもので，二つ のパーツからなる成形品に, 吸収材料, 抗体等を組み込み, 接着したものである。大きさは， $80 \mathrm{~mm} \times 20 \mathrm{~mm} \times 5 \mathrm{~mm}$ であ る。サンプル滴下ロに, 抽出液を滴下すると図に示すよう に液が流れる構造になっている。Fig. 7(b)に, ラテラルフロ ーキットの内部構造を示す。滴下された抽出液は, 磁気ビ 一ズ標識体と反応しながら, 反応部に流れていく。ラテラ ルフローキットでは, 非常に細い溝を利用した毛細管現象 により, 抽出液・磁気ビーズ標識物質を反応部に導く構造 となっていることが特徴である。溝は $0.2 \mathrm{~mm} \times 0.4 \mathrm{~mm}$ の開 口を持つ。

また，Fig. 7(a)からわかるように，反応部空間は微小空間 となるように設計されており, 空間厚みは $0.15 \mathrm{~mm}$ となって いる。これは免疫反応効率を向上させるためである。この 空間を実現するために, 成形体の一部は， $0.1 \mathrm{~mm}$ の厚みと なっており, 精密射出成形で実現した。

反応部に到達した被検出物質及び磁気ビーズ標識体は免 疫反応により, 反応部に吸着され, 反応に寄与しなかった 磁気ビーズは，毛細管現象により洗い流される。

被検出物質が存在しない場合には, 磁気ビーズ標識物質 反応部で免疫反応せず，毛細管現象により洗い流される。

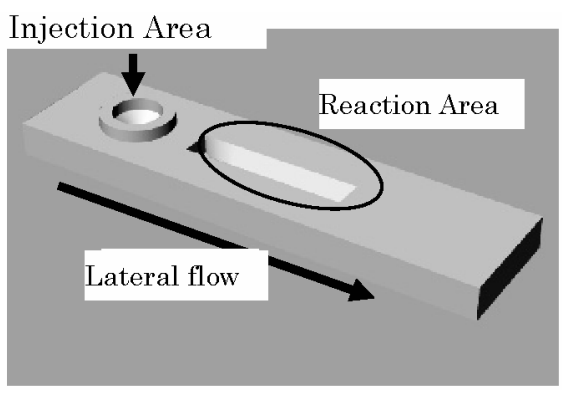

(a)

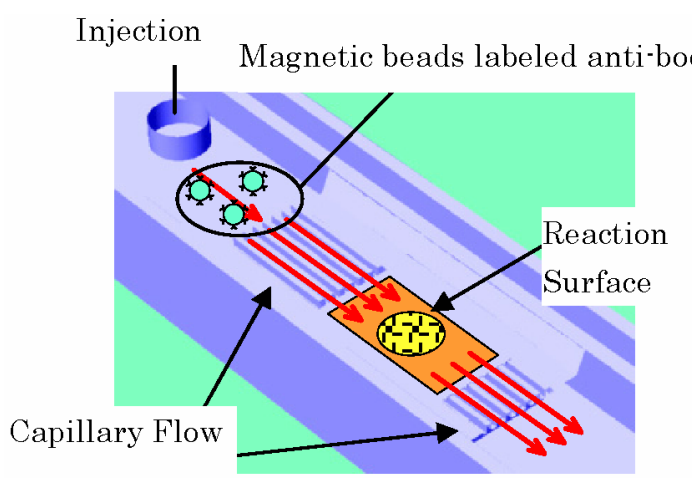

(b)

Fig. 7. Lateral flow kit for immunoassay 


\section{5. 迅速診断システムの試作}

〈5·1〉装置開発 プロトタイプIに示したように， SMR 素子に対して, 磁気ビーズを一方向に水平走査するこ とを設計思想とし，迅速診断装置を開発した。 装置感度向上のために,

・信号増幅初段にローノイズのプリアンプを使用

・1/fノイズ及びジョンソンノイズ除去のために バンドパスフィルタを使用。

カットオフ周波数 $15.9 \mathrm{~Hz}, 41.3 \mathrm{~Hz}$

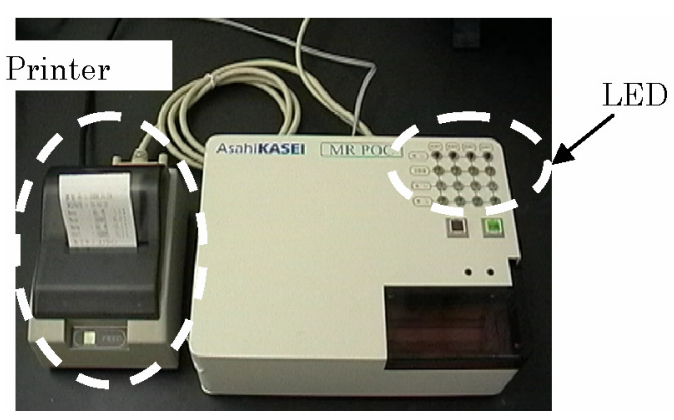

(a)

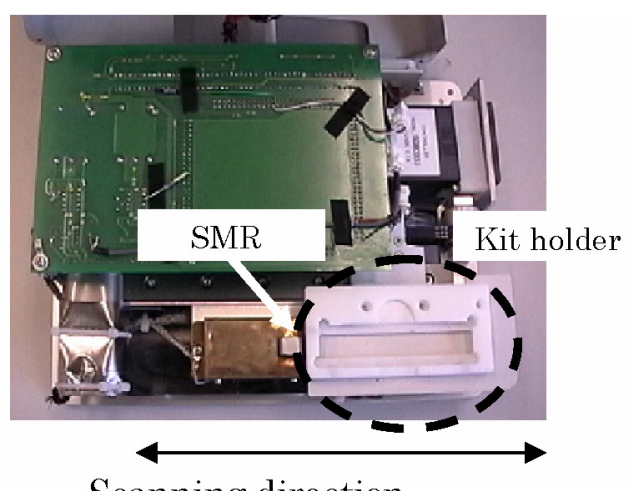

Scanning direction

(b)

Fig. 8. Machine for magnetic beads detection

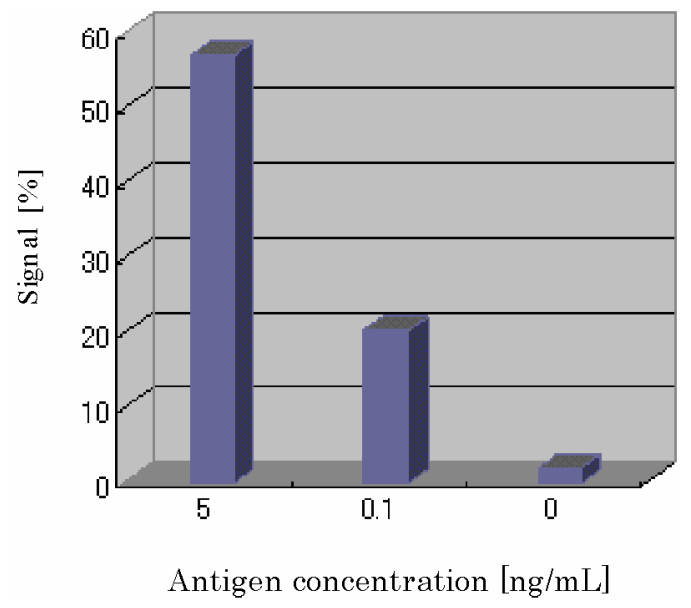

Fig. 9. Evaluated result of test machine (anti-gen of H.Influenza)
・装置部品からのノイズ除去のためのセンサの磁気シ ールド

・ A/D コンバーター起因の信号オフセットドリフトを 除去するための FFT 処理

・ランダムノイズ除去のための積算処理（25 回）

の対策を行った。

このようにして完成した装置を Fig. 8 に示す。

Fig. 8(a)は装置外観であり, 装置本体の大きさは $260 \mathrm{~mm} \times$ $200 \mathrm{~mm} \times 90 \mathrm{~mm}$ と小さく, 重量も $3 \mathrm{~kg}$ と軽く, 容易に持ち運 びも可能である。LED 表示することで, 被検出物質の半定 量結果が容易にモニターでき, 定量結果が必要な場合は, プリンタを接続し数值を表示できる。測定時間はラテラル フローキットにより免疫反応を行った後, 約 40 秒と短い。

Fig. 8(b)は，装置内部構造である。免疫反応後のラテラル フローキットを装置に装着し，SMR 素子に対して水平に走 査することで信号を検出する。

〈5·2〉迅速診断システム評価今回, 開発した装置 及びラテラルフローキットを用いて, 免疫反応を行った結 果を Fig. 9 に示す。縦軸の装置出力は, A/D 変換後のデジタ ル信号出力である。被検出物質としては, H.Influenza 菌を 用いた。Fig. 9 からわかるように, 検出信号は抗原濃度とと もに変化しており，また検出限界が $0.1 \mathrm{ng} / \mathrm{mL}$ 以下と非常に 高感度なシステムであることを実証した。この值は，被検 出物が異なるため, 一概に比較できるものではないが, CRP (C-reactive Protein) の検出例として, $0.25 \mu \mathrm{g} / \mathrm{mL}$ という報告 ${ }^{(4)}$, 腫瘍マーカー（PSA）の検出例として，0.25ng/mL という報 告(5)から見て, 十分な感度であると言えよう。

実際の医療現場での使用を考えると，検体の採取は，患 者の咽頭，鼻腔から綿棒（スワブ）を用いて採取すればよ く, 患者の負担も, 現在よく用いられている, インフルエ ンザウイルス診断キットと同等である。

我々が今回開発したシステムは，「簡便性」「高汎用性」 「定量可能」「システムの小型化」「安価」などの特徵を備え ており，感染症診断・環境検查の場に好適である。

\section{謝 辞}

本開発にあたり，免疫アッセイの助言，実施をいただい た，東京女子医科大学の杉原茂孝教授，鈴木葉子先生，旭 化成グループの渡邊勝哉，藤村眞理子，五月女勲，生田茂， 望月雅子，遠藤藍の各氏に感謝いたします。（各氏の所属は 当時の所属）

(平成 22 年 5 月 21 日受付, 平成 22 年 7 月 30 日再受付)

\section{文献}

（1）満田年宏：「小児科臨床 Japanese journal of pediatrics」, Vol.56, p.1282 (2003)

（2）大川洋二：「感染症迅速診断キット活用の現況」, 日小医会報, The Journal of the Japan Pediatric Association, Vol.27, pp.11-14 (2004)

(3) 特許公報: 特許第 4237045 号

（4）公開特許公報：特開 2010-25887

(5) 特許公報：特許第 4514233 号 


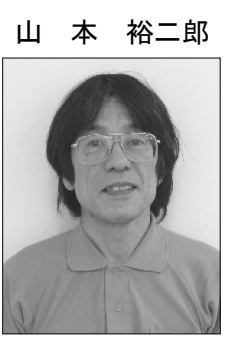

（非会員） 1953 年 9 月 10 日生。1981 年 3 月早 稲田大学理工学研究科修了。同年, 旭ダウ (株) 入社。樹脂加工の研究開発を経て, リチウムイ オン二次電池の開発, 診断システムの開発など を担当後, 現在, 旭化成イーマテリアルズ (株) にて, ワイヤーグリッドフィルムの開発に従事。

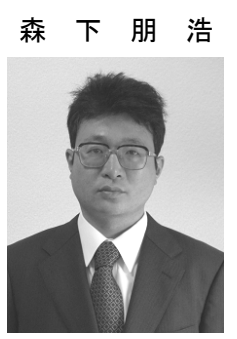

（非会員） 1974 年 8 月 13 日生。1997 年 3 月東 京大学工学部応用化学科卒業。1999 年 3 月同大 大学院修士課程応用化学専攻修了。同年旭化成 工業（株）入社。現在旭化成エレクトロニクス （株）研究開発センターにて, 半導体薄膜を用 いた光センサの開発に従事。

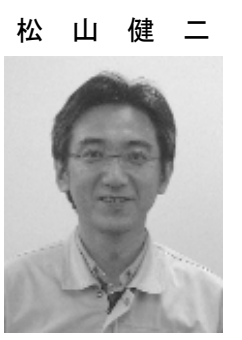

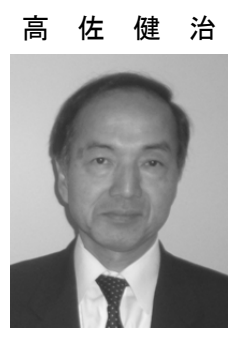

(非会員) 1950 年 9 月 29 日生。1973 年 3 月大 阪大学基礎工学部化学工学科卒業。1975 年 3 月同大大学院修士課程化学工学専攻修了。同年 旭化成工業 (株) 入社。現在旭化成 (株) 研究 開発センターにて, ポリマー加工に関する研究 に従事。高分子学会, 日本材料学会会員。旭化 成グループフェロー。博士 (工学)。

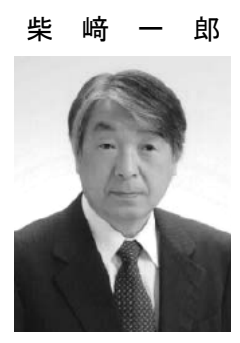

（正員） 1971 年 3 月東京教育大学大学院修了。 東京教育大学理学部物理教室勤務を経て, 1974 年旭化成工業 (株) 入社, 技術総合研究所技術 研究所室長, 旭化成グループフェロー兼柴崎研 究室長等を経て, 現在は, (財) 野口研究所顧 問の他, 東京工業大学大学院生命理工学研究科 特任教授, 豊橋技術科学大学特命教授を務め る。2003 年紫綬褒章受章。博士 (理学)。 